\title{
The Use of Assistance Computer Word Processor to Teach Writing Skill For EFL learners
}

\author{
Zulfa Azizaturrohmi
}

MA Mu'allimat NW Pancor, Indonesia

Correspondence: Zulfa Azizaturrohmi, Indonesia. e-mail: ulfhakocietd@gmail.com

Received: November 28, 2018

DOI: $10.29408 /$ veles.v3i1.1021.g739
Accepted: Februari 22, $2019 \quad$ Online Published: April 15, 2019

URL: http://dx.doi.org/10.29408/veles.v3i1.1021.g739

\begin{abstract}
This study aimed at determining the effectivenes of Assistance of Computer Word Processor to teach writitng skill for the eleventh grade students of MA Muallimat NW Pancor in the school year 2017-2018. The purpose of the study were to find whether or no Assistance Computer Word Processor is effective in teaching writing skill for the eleventh grade students of MA Muallimat NW Pancor. This research used pre-experimental design which uses onegroup pretest-postest design.The population of this research was all of the eleventh grade students, whichnamely Natural Science and as the sample was eleventh four Sience class. The instrument used in this resarch was essay test where used hortatory exposition text. The researcher gave a pre test in the fisrt meeting, treatment, and post test in the last meeting. The result of mean score of pre-test was (30.93) and the mean score in post-test was (69.06). The researcher found that there was significant difference between the mean score before and and after treatment, $\mathrm{t}(\mathrm{df}=29)=48.42$ at $p=0.000$. After conducted the research, present researcher found that using Assistance Computer Word Processor was significantly effective in teaching writing skill for eleventh grade students of MA Muallimat NW Pancor.
\end{abstract}

Keywords: Assistance Computer Word Processor, hortatory exposition text, writing skill

\section{Introduction}

Language is the tool of communication among human beings. In globalization era or free trade era, language is very important especially in science and technology sector to build relationship among countries in the world. English is one of languages in the world and an international language, and the first foreign language in Indonesia. Since it is an international language, English is necessary to be mastered by generation of a nation, especially for students in order to be able to adapt and to compete in the international world.

The four skills of English are the important things to learn during the teaching and learning process. To teach those skill, some method used to apply the skills whether receptive or productive in which a foreign language is taught.

Among those four skills, writing is the difficult skill to teach. Writing is one of the language skills that should be mastered by Indonesian students in learning English. Even most 
of the students think that writing class is boring and difficult because the teacher's way or method to teach writing rather monotonous and the students are not well motivated to practice their writing skill. Regarding to this phenomenon English teachers should be able to create learning atmosphere as enjoyable as possible in order the process of transferring English writing knowledge and skill will be easier and more interesting, thuscan help improve the students skill and enhance their learning experience. Harmer (2001) pointed out that "there are a number of reason why students find language production dufficult". Writing and learning to write has always been one of the most complex language skill.

Some problems in writing skill when students write some texts are, lack of vocabularies, have no idea what students want to write, and lack of grammar. However as long as students want to try it they are and supported with interesting media, students will be more motivated to write eventhough writing is one of difficult skill but students have to be master. Related to those problems, the present researcher used Computer Word Processor as the media to write.

Computer Word Procesor is an electronic device or computer software application that performs the task of composing, editing, formating, and printing of document. Based on the researcher experience, some of school used Computer Word Processor to write text, even it is used to do simulation for examination. It just the utilizing not intensive. In this type of instruction, students might work collaboratively on writing assignments using personal laptop, computers, or they might learn to word-process a composition under teacher guidance.

Word processing program is a helpful tool in improving students writing. Eyres (2007, p. 210) assures that "there can be no doubt that the editing facility offered by computers has revolutionized our attitudes to mistakes." if students have access to computers at schools, computers will greatly be beneficial and supporting students' writing. Harmer (2001, p.261). Students might work collaboratively on writing assignments using personal laptop computers, or they might learn to word-process a composition under teacher guidance.Typing text on the computer with word-processing software produces a neat and legible script. It allows the writer to add, delete, and move text easily.This study is about testing the effectiveness of using the word processor with English Foreign Learner (EFL)

The present research chooses Word Processor in teaching writing at MA Mu'allimat NW Pancor because by using the word processor for their writing, it's interesting and students could produce longer and higher quality writing.

\section{Method}

This research used pre-experimental design. Pre-experimental design is simple and inexpensive to implement and exploratory in nature. In addition, Pre-experimental design does not have random assignment of subject to group or other strategies to control extraneous variables

The design of this research is pre-experimental design which uses one-group pretestposttest design, "one group pretest-posttest design usually involves three steps: (1) administering a pretest measuring the dependent variable; (2) applying the pre-experimental treatment $\mathrm{X}$ to the subject; and (3) administering a posttest, again measuring the dependent 
variable". Differences attributed to application of the pre-experimental treatment are then evaluated by comparing the pretest and posttest score.

\subsection{Participants}

The population of this research is all the eleventh grade students at MA Mu'allimat $N W$ Pancor in the academic year 2017-2018, which were divided into 3 classes namely Natural Science major. The researcher chose IPA 3 as the sample of this study and the class consists of 30 students.

\subsection{Data Collection}

\subsubsection{Instrument of Collecting Data}

The instrument of this research was written test where used hortatory exposition text, the researcher asked the students to write hortatory exposition text in the pre-test to using Word Processor to know students ability before gave the treatment using Word Processor.

\subsubsection{Techniques for Collecting Data}

Pre-test is a test given to students before the treatment. The researcher started the research by giving pretest to the students. The pretest was conducted on April $16^{\text {th }}, 2018$ by giving the students essay test. At the first meeting, researcher asked the students to write hortatory exposition text using word processor as the media of this research.

This treatment consisted of four meetings, the first meeting on April 16thto April 24th. The research was conducted in the computer laboratory, and students started to open the computer to read the explanation before do the exercise. At the first meeting, the researcher explain the students about the media that they will use and explain what is

The post test was held on April 26th. The post test was administrated by giving essay to the students. In general, posttest was aimed to know whether there was any significance difference in achievement using before and after giving the treatment by using the Assistance computer word processor. The students were given 90 minutes to do the test.

\subsection{Data Analysis}

In this study, the present researcher used descriptive statistics to analyze the data. The present researcher finds the mean score (M) and standard deviation (SD) of studentse score. To get the mean score in the pre-test and post-test, the present researcher uses SPSS 22 for windows.

After analyzing the data the present researcher found that there was a significant difference in the mean scores between the pre-test and post-test, $t(d f=29)=48.42$ at $p=0.000$ meaning that the hypothesis was rejected and alternative hypothesis was accepted. It meant that Assistance Computer Word Processor was significantly effective to teach writing skill for the eleventh grade of MA Muallimat NW Pancor. 


\section{Findings}

During the research, the researcher assessed based on the criteria of writing that were content, organization, grammar (language use), mechanic and vocabulary. For those assessments the researcher give 1-5 score for each aspect. To know how far and how much the score will be given to the students; the researcher used hortatory exposition text and Assistance Computer Word Processor to write the text.

Referring to the data gained in pre-test, the result of students was as follows: in the pretest the lowest score was 16 and the highest score was 52, while in the post-test, the lowest score was 56 and the highest score was 80 . In pre-test there were four students got highest score and the lowest score was four students, while in post-test there were four students and the lowest score was three students. In addition, the mean score of pre-test was 30.93 while post-test 69.06. The mean scores of post-test were higher than the mean scores of pre-test. It meant that the Assistance computer word processor had the significantly effective in improving the students' writing skill.

\section{Discussion}

After analyzing the data based on the scoring rubric, the researcher found that grammatical and spelling erorrs everywhere in students writing before giving the teratment. At the first meeting, when conducting the pre-test, the students's result was very poor. More than half of the students have difficulties in grammar and spelling. Grammar always is the main problem for EFL students. They have difficulties in how sentences structured and the different types of tenses. In parallel to grammar, and spelling are also problems for some students.

Referring to the post-test result, the researcher used the Word Processor as the media to write, hoping that the students can improve and motivate their writing skill. At the second meeting the researcher gave the treatment using Word Processor the whole meeting. Hortatory exposition text used in this research as the instrument. After the researcher explains about the media and instruments will be used, the researcher asked students started to write their own sentences based on the hortatory exposition text rule.

At the end of the treatment, the researcher analyzed the data and found the result which was quite surprising. However, the students result was improve before giving the treatment. Those problems that students faced were grammar and spelling was decreased. Not only grammar and spelling was improving but the punctuation also, through the Word Processor the students easier to know which word that wrong or typo because it was set automatically. It is different when they write using pen and paper. The students must be considered with the spelling. If the researcher count in percentages, the increase of those problems was very good. The most important things were the result of pre-test and post-test was significantly different.

After conducting the research, the present researcher found that using Assistance computer word processor was effective in teaching writing skill for eleventh grade students of MA Mu'allimat NW Pancor and it proved that it was same as the theory the present 
researcher used. There is no doubt that the Word Processor was helpful tool in improving students writing skill.

As the expert says that, Harmer (2001) recommends teachers to encourage their students to write emails in English to others around the world as he considers this "extremely motivating" and more exciting than other forms of letter writing. Therefore, this course has proved the utility of using the word processing program in improving students' writing skill in ESL classroom. Those theory was supported the researcher research and after conducting the research, the researcher found that using the computer word processor were it helps them and makes the task of writing easier and more neat than by hands.

The conclusion of the discussion was the students see that the computer is completely different from handwriting. This distinction does not deny that each one has its own benefits and drawback on student's writing. From those advantages of using the computer were it helps them and makes the task of writing easier than the usual (by hands). It really has a favor in facilitating and developing students' writing especially those who study foreign language, but this does not make it the only way to write. It can be concluded that Assistance computer word processor was effective to teach students' writing skill for eleventh grade.

\section{Conclusions}

Referring to the result of the research, the pesent researcher synthesizes briefly some conclusions. The students' mean score in post-test was higher than in the pre-test, it means that there was a significant difference in the mean scores between the pre-test and the post-test, 0.85 and 0.135 . It means that the hypothesis was accepted. Using Assistance Computer Word Processor is significantly effective in teaching writing for the eleventh grade students of MA Muallimat NW Pancor. There is no doubt that the Word Processor was helpful tool in improving students writing skill.So, they at least know to write a short piece of writing and save it. For them, it is necessary nowadays to use the computer to learn and to write their works or for entertaining. Despite of studentse using of the computer, they think it is preferable to use their hands instead of it to write. They see that the computer is completely different from handwriting. This distinction does not deny that each one has its own benefits and drawbacks on studentse ${ }^{\text {ee }}$ writing. From those advantages of using the computer are: it helps them and makes the task of writing more easy than the usual (by hands); it supplies immediate corrections in case of there is a mistake; it can save all the written information; it gains time. Actually those students mentioned the great things giving by the computer, but they see that handwriting is still the best solution that make them comfortable when write.

\section{References}

Brown, H. (2004). Language assessment: principles and classroom practice. New York:

Burns, n \& Grove, SK 2003: The practice of nursing research: Conduct, critique and utilization. Toronto: WB Saunders. 
Davis, J. R., Mitchell, J., \& Milner, J. (2012). Seeing double: Visual media and expanding definitions of literacy in the English classroom. Studies in Teaching 2012 Research Digest, 19-24. Retrieved from ERIC database (ED533608). http://

Duran ,(2013 , p.6)The improvement of writing based on a genre approach through the use of an e-learning platform. Unpublished master's thesis. University of Veracruz, Mexico

Damayanti. (2010). Micro and macro skills of writing found in the writing exercises of the bridge English competence for SMP grade viii 2010 published by Yudhistira. Unpublished undergraduate thesis. English Department, Faculty of Languages and Arts Semarang State University, Indonesia.

Eyres, I. (2007). English for primary and early years. Los Angeles: Sage Publication.

Graham, S. (2008). The power of word processing for the students. Winconsin: Renaissance Learning Incorporation.

M. Murray, Donalds. (1972). Teaching writing as a process not product. reprint from the leaflet, pg 4-5.

Moedjito.(2014). Basic statistic for research in language education. Unpublished Modul: STKIP Hamzanwadi Selong, Nusa Tenggara Barat, Indonesia.

Suharsimi. (2006). Prosedur penelitian suatu pendekatan praktik. Jakarta: Rineka Cipta. 